DOI: $10.25140 / 2411-5363-2021-3(25)-256-264$

УДК 621.316 .11

\author{
Вадим Бодунов ${ }^{1}$, Ігор Діхтярук ${ }^{2}$ Андрій Красножон ${ }^{3}$ \\ ${ }^{1}$ кандидат технічних наук, доцент кафедри електричної інженерії та інформаційно-вимірювальних технологій \\ Національний університет «Чернігівська політехніка» (Чернігів, Україна) \\ E-mail: vad1979@ukr.net. ORCID: https://orcid.org/0000-0003-2882-5787 \\ ${ }^{2}$ кандидат технічних наук, доцент кафедри електричної інженерії та інформаційно-вимірювальних технологій \\ Національний університет «Чернігівська політехніка» (Чернігів, Україна) \\ E-mail: dihtyaruk.ihor@gmail.com. ORCID: https://orcid.org/0000-0002-6565-6356 \\ ${ }^{3}$ кандидат технічних наук, доцент, доцент кафедри електричної інженерії \\ та інформаційно-вимірювальних технологій \\ Національний університет «Чернігівська політехніка» (Чернігів, Україна) \\ Email: red john@ukr.net. ORCID: https://orcid.org/0000-0002-6215-7535
}

\title{
МАТЕМАТИЧНЕ МОДЕЛЮВАННЯ ПІКОВИХ СТРУМІВ ПРИ ВКЛЮЧЕННІ СВІТЛОДІОДНИХ ДЖЕРЕЛ СВІТЛА
}

Включення блоків жсияення, які зазвичай використовуються в однофазних електроприймачів з нелінійним навантаженням, супроводжується імпульсом струму, який може в декілька разів перевишувати струм спрацювання апаратів захисту і призводити до їх відключення. збільшенням кількості офісних приміщень з комп'ютерним обладнанням, а також однофазних електроприймачів з нелінійним навантаженням або імпульсними блоками живлення, виникає проблема зниження ефективності електропостачання, яка полягає в некоректному спрацюванні захисних апаратів.

Ключові слова: нелінійні приймачі електроенергї; математична модель; комутація; піковий струм; світлодіодне джерело світла.

Рис.: 8. Бібл.:9.

Актуальність теми дослідження. В наш час, зі стрімким збільшенням кількості офісних приміщень 3 комп'ютерним обладнанням, а також однофазних електроприймачів 3 нелінійним навантаженням та інших приймачів, наприклад, з імпульсними блоками живлення, виникає проблема зниження ефективності та погіршення якості електропостачання: некоректне спрацювання захисних апаратів в мережах освітлення, силових електричних мережах офісних будівель та приватному секторі, при роботі автоматичного вводу резерву чи автоматичного повторного включення.

Це пов'язано з тим, що з розвитком технологій зменшується встановлена потужність однофазних приймачів, що приводить до зменшення навантаження на одиничні внутрішньобудинкові електричні мережі. Внаслідок цього, при виборі апаратів захисту під час проектування або реконструкції, використовують автоматичні вимикачі з меншими номінальними струмами.

Блоки живлення, які зазвичай використовуються у однофазних електроприймачів 3 нелінійним навантаженням, в момент включення споживають значний струм, що приводить до виникнення імпульсу струму незначної тривалості під час включення. При використанні в мережі незначної кількості таких приймачів амплітуди імпульсу струму недостатньо для спрацювання апаратів захисту. Проте при збільшенні кількості таких приймачів в момент одночасного включення пікове значення струму може в декілька разів перевищувати струм спрацювання апаратів захисту, і, відповідно, може приводити до їх відключення.

Постановка проблеми. Очевидно, що спочатку слід виявити основні особливості перехідного процесу при підключенні до низьковольтної електричної мережі окремої світлодіодної лампи чи світильника. Саме тому дана робота присвячена математичному моделюванню пікових струмів при включенні світлодіодних джерел світла.

Аналіз останніх досліджень і публікацій. Світлодіодні джерела світла в наш час широко використовуються не тільки в комунально-побутовому секторі, а й у промисловості, на об'єктах транспортної інфраструктури. Частина таких джерел обладнано системою, що забезпечує плавне включення джерела. Однак, такі джерела достатньо дорогі, тому найбільшого поширення набули більш прості за конструкцією джерела, де процес (c) Бодунов В. М., Діхтярук I. В., Красножон А. В., 2021 
включення є стрімким та супроводжується появою значного струму та в окремих випадках перенапруги на конденсаторі [1-4]. Часто це призводить до виходу самого джерела світла з ладу, найчастіше, з двох причин - перегорає діодний міст або ж виходить 3 ладу конденсатор. За умови одночасного включення великої групи таких джерел в низьковольтній електричній мережі можуть виникати провали напруги [5-7], що може негативно вплинути на роботу інших наявних у мережі приймачів енергії, також значний струм на початку цього процесу може призводити до відключення автоматичного вимикача через спрацьовування електромагнітного розчеплювача.

Виділення недосліджених частин загальної проблеми. В даний час не існує остаточної методики вибору апаратів захисту в електричних мережах з світлодіодними джерелами світла. Для виключення проблеми спрацювання апаратів захисту при включенні в таких мережах проектувальники та монтажні організації використовують апарати захисту із завищеним номінальним струмом спрацювання, що приводить до зниження чутливості основного захисту. Тому дуже важливим є дослідження перехідних процесів при підключенні до низьковольтної електричної світлодіодних джерел світла для вибору їх оптимальної кількості та параметрів апаратів захисту.

Мета дослідження. На основі математичного моделювання дослідити особливості перехідного процесу при підключенні до низьковольтної електричної світлодіодних джерел світла.

Виклад основного матеріалу. Світлодіодні джерела світла в наш час широко використовуються не тільки в комунально-побутовому секторі, а й у промисловості, на об’єктах транспортної інфраструктури. До особливостей конструкції таких джерел світла слід віднести наявність в них випрямляча (діодного мосту) та конденсатора, а також i драйвера світлодіодів, який вмикається при досягненні певного рівня напруги конденсатора [8] (рис. 1).

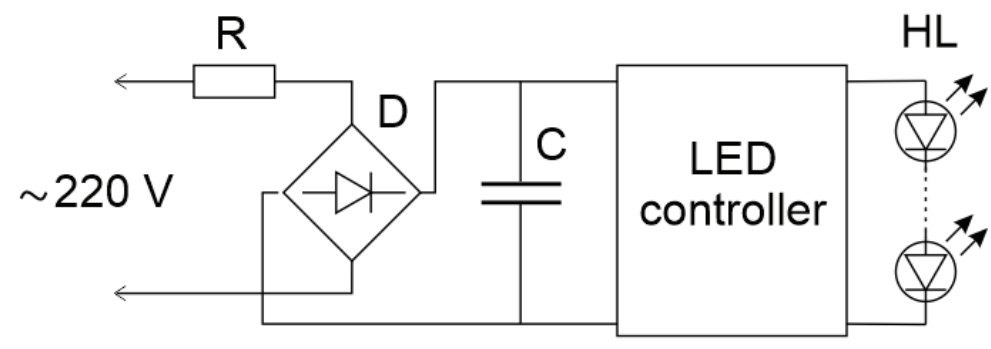

Рис. 1. Типова конструкція світлодіодного світильника

По відношенню до навантаження низьковольтна електрична мережа може бути представлена значенням синусоїдальної ерс e(t) та еквівалентним активно-індуктивним опором, що дорівнює опору петлі «фаза-ноль» (елементи $\mathrm{R}_{\mathrm{S}} \mathrm{Ta} \mathrm{L}_{\mathrm{S}}$ на рисунку 2), разом із цим, при використанні кабельних мереж, доцільно додатково врахувати еквівалентну ємність кабельних ліній $\mathrm{C}_{\mathrm{S}}$, яка складає біля 0,4 мкФ/км. Інші приєднані до мережі навантаження можуть бути задані у вигляді еквівалентної активно-індуктивної провідності (опори $\mathrm{R}_{\mathrm{L}} \mathrm{Ta} \mathrm{L}_{\mathrm{L}}$ ).

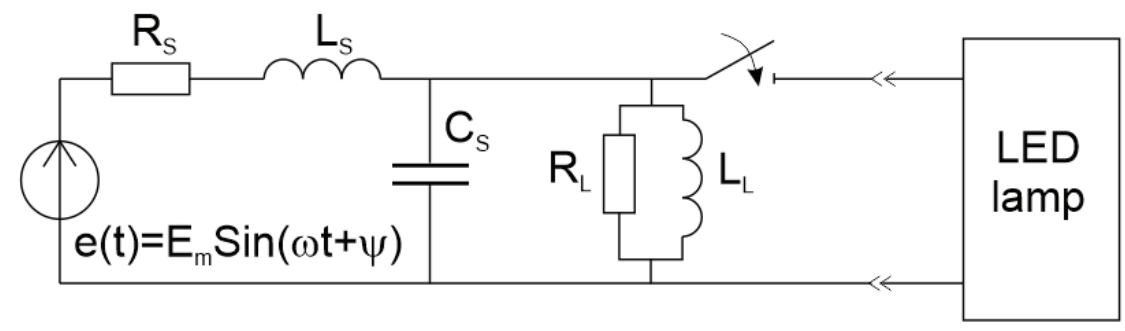

Рис. 2. Еквівалентна схема зовнішньої електричної мережі при приєднанні світлодіодного світильника 
Враховуючи багатопараметричність отриманої електричної мережі було прийнято рішення для формування аналітичних залежностей використати ряд спрощень:

- нехтування ємнісною провідністю ліній електропередавання. Даний випадок відповідає електричній мережі з переважно повітряними лініями електропередачі, що характерно для приватного сектору міст та сільських регіонів;

- оскільки, за попередніми оцінками, заряджання конденсатора С відбувається за 24 мс, прийнято рішення в аналітичній моделі розглядати синусоїдальне джерело без діодного мосту;

- найбільш важкі умови включення будуть відповідати випадку, коли до вхідного опору електричної мережі приєднується лише даний світильник за відсутності інших навантажень, що враховується безкінечним опором навантажень $\left(\mathrm{R}_{\mathrm{L}}=\infty, \mathrm{L}_{\mathrm{L}}=\infty\right)$.

Таким чином, в першому наближенні можна розглядати процес включення світлодіодного джерела світла, як процес включення кола з послідовним з'єднанням резистора, котушки та конденсатора на синусоїдальну напругу [9]. При цьому слід зазначити, що найбільше перехідний процес включення буде виявляти себе саме в першому напівперіоді підведеної синусоїдальної напруги, коли перед початком перехідного процесу маємо розряджений конденсатор. У наступному напівперіоді конденсатор буде вже зарядженим до деякої напруги, тому і перехідний процес проявлятиметься меншою мірою, ніж у попередньому випадку.

Розглянемо процес включення кола з послідовним з'єднанням резистора, котушки та конденсатора на синусоїдальну напругу (рис. 3).

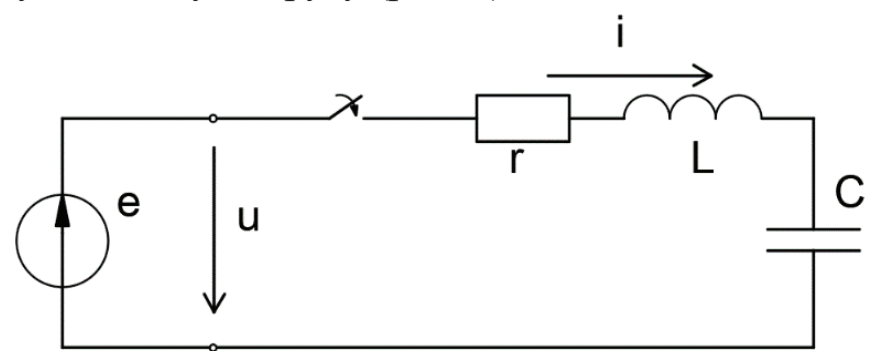

Рис. 3. Схема включення послідовного $R, L, C$ кола на синусоїдальну напругу

Вхідна напруга змінюється за синусоїдальним законом:

$$
u=U_{m} \cdot \sin \left(\omega t+\psi_{u}\right) ; \quad u(0)=U_{m} \cdot \sin \psi_{u} .
$$

де $U_{m}$ - амплітуда вхідної напруги; $\omega t$ - кутова швидкість; $\psi_{u}$ - початкова фаза вхідної напруги; $u(0)$ - вхідна напруга в початковий момент часу.

Перехідну функцію для струму можна найти як суму вимушеної та вільної складової:

$$
i=i^{\prime}+i^{\prime \prime}
$$

де $i^{\prime}$ - вимушена складова струму; $i^{\prime \prime}$ - вільної складова струму.

Для знаходження вимушеної складової необхідно розглянути усталений режим після комутації (Рис. 4).

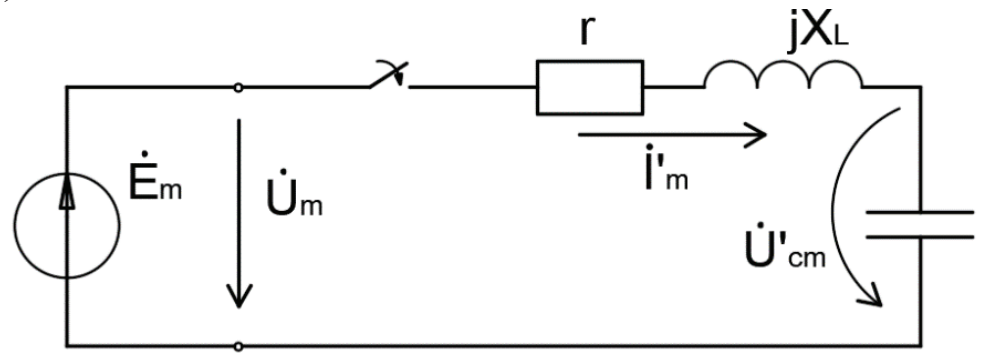

Рис. 4. Розрахункова схема усталеного режиму після комутації 
TECHNICAL SCIENCES AND TECHNOLOGIES

Для знаходження комплексної амплітуди струму скористаємось законом Ома, який в символічній формі для схеми, зображеної на (рис. 4) набуває вигляду

$$
\dot{I}_{m}=\frac{\dot{U}_{m}}{Z}=\frac{U_{m} \cdot e^{j \psi_{u}}}{z \cdot e^{j \phi}}=\frac{U_{m}}{z} \cdot e^{j\left(\psi_{u}-\phi\right)} .
$$

де $Z$ - повний опір кола.

Миттєве значення вимушеної складової перехідного струму дорівнює:

$$
i^{\prime}=\frac{U_{m}}{z} \cdot \sin \left(\omega t+\psi_{u}-\varphi\right)
$$

У випадку електричного кола другого порядку залежно від величини активного опору процес може бути аперіодичним, гранично-аперіодичним та коливальним. Тому розглянемо кожен варіант окремо.

\section{Аперіодичний перехідний процес}

Для того, щоб процес був аперіодичним, має виконуватись умова, що активний опір кола більше критичного, тобто:

$$
R>R_{\kappa p}, R_{\kappa p}=2 \sqrt{\frac{L}{C}} .
$$

де $R$ - активний опір кола; $R_{\kappa p}$ - критичне значення активного опору кола; $L-$ індуктивність кола; $C-$ - мність кола.

Вираз для вільної складової струму потрібно шукати у вигляді:

$$
i^{\prime \prime}=A_{1} \cdot e^{p_{1} t}+A_{2} \cdot e^{p_{2} t},
$$

де $P_{1,2}=-\frac{R}{2 L} \pm \sqrt{\frac{R^{2}}{4 L^{2}}-\frac{1}{C}} ; A_{1}, A_{2}-$ постійні інтегрування; $p_{1,2}-$ комплексноспряжені корені характеристичного рівняння.

Повний розв'язок для перехідного струму запишемо у вигляді:

$$
i=i^{\prime}+i^{\prime \prime}=\frac{U_{m}}{z} \cdot \sin \left(\omega t+\psi_{u}-\phi\right)+A_{1} \cdot e^{p_{1} t}+A_{2} \cdot e^{p_{2} t}
$$

Постійні інтегрування $\mathrm{A}_{1}$ та $\mathrm{A}_{2}$ знаходимо із граничних умов із урахуванням I та II законів комутації. У випадку прийнятих припущень маємо $i(0)=0 ; u_{C}(0)=0$. Тоді шукане значення струму складе

$$
\begin{gathered}
i=i^{\prime}+i^{\prime \prime}=\frac{U_{m}}{z} \cdot \sin \left(\omega t+\psi_{u}-\varphi\right)+A \cdot e^{p_{1} t}+A_{2} e^{p_{2} t}= \\
=\frac{U_{m}}{z} \cdot \sin \left(\omega t+\psi_{u}-\varphi\right)+\left[\frac{\frac{U_{m}}{z} \cdot\left(\omega \cdot \sin \left(\psi_{u}-\varphi+90^{\circ}\right)-p_{2} \cdot \sin \left(\psi_{u}-\varphi\right)\right)-\frac{u(0)}{L}}{p_{2}-p_{1}}\right] \cdot e^{p_{1} t}+ \\
+\left[\frac{-\frac{U_{m}}{z} \cdot\left(\omega \cdot \sin \left(\psi_{u}-\varphi+90^{\circ}\right)-p_{1} \cdot \sin \left(\psi_{u}-\varphi\right)\right)+\frac{u(0)}{L}}{p_{2}-p_{1}}\right] \cdot e^{p_{2} t} .
\end{gathered}
$$


TECHNICAL SCIENCES AND TECHNOLOGIES

\section{Гранично-аперіодичний процес}

Для формування гранично-аперіодичного процесу має виконуватися умова

$$
R=R_{\kappa p}=2 \cdot \sqrt{\frac{L}{C}} ;
$$

У цьому випадку

$$
i^{\prime \prime}=\left(A_{1}+A_{2} t\right) e^{p t}=A_{1} \cdot e^{p t}+A_{2} t \cdot e^{p t} .
$$

де $p=-\frac{R}{2 L}$.

Після знаходження постійних інтегрування маємо остаточний вираз:

$$
\begin{gathered}
i=i^{\prime}+i^{\prime \prime}=\frac{U_{m}}{z} \cdot \sin \left(\omega t+\psi_{u}-\varphi\right)+ \\
+\left[-\frac{U_{m}}{z} \cdot \sin \left(\psi_{u}-\varphi\right)+\left(\frac{u_{L}(0)}{L}-\frac{U_{m}}{z} \cdot \omega \cdot \sin \left(\psi_{u}-\varphi+90^{\circ}\right)+\frac{U_{m}}{z} \cdot p \cdot \sin \left(\psi_{u}-\varphi\right)\right) \cdot t\right] \cdot e^{p t}= \\
=\frac{U_{m}}{z} \cdot \sin \left(\omega t+\psi_{u}-\varphi\right)+ \\
+\left[-\frac{U_{m}}{z} \cdot \sin \left(\psi_{u}-\varphi\right)+\left(\frac{u_{L}(0)}{L}-\frac{U_{m}}{z} \cdot\left(\omega \cdot \sin \left(\psi_{u}-\varphi+90^{\circ}\right)+p \cdot \sin \left(\psi_{u}-\varphi\right)\right)\right) \cdot t\right] \cdot e^{p t} \cdot
\end{gathered}
$$

Коливальний процес

Для формування коливального процесу має виконуватися умова:

$$
R<R_{\kappa p}, R_{\kappa p}=2 \cdot \sqrt{\frac{L}{C}} .
$$

У цьому випадку вільна складова має коливальний характер:

$$
i^{\prime \prime}=A \cdot e^{-e t} \cdot \sin \left(\omega_{p} \cdot t+\psi_{p i}\right)
$$

де $A, \psi_{p i}$ - постійні інтегрування; $p_{1,2}$ - комплексноспряжені корені характеристичного рівняння.

$$
\begin{gathered}
P_{1,2}=-b \pm j \omega_{p}, \text { де } b=\frac{R}{2 L} ; \omega_{p}=\sqrt{\frac{1}{L C}-\frac{R^{2}}{4 L^{2}}} ; \\
\omega_{p}=\sqrt{\omega_{0}^{2}-b^{2}} .
\end{gathered}
$$

Остаточний вираз для струму має вигляд:

$$
\begin{gathered}
i=i^{\prime}+i^{\prime \prime}=\frac{U_{m}}{z} \cdot \sin \left(\omega t+\psi_{u}-\varphi\right)+A e^{-b t} \cdot \sin \left(\omega_{p} t+\psi_{p i}\right)= \\
=\frac{U_{m}}{z} \cdot \sin \left(\omega t+\psi_{u}-\varphi\right)+\frac{\frac{U_{m}}{z} \cdot \sin \left(\psi_{u}-\varphi\right)}{\sin \psi_{p i}} \cdot e^{-b t} \cdot \sin \left(\omega_{p} t+\psi_{p i}\right) .
\end{gathered}
$$

Характер протікання перехідного процесу в значній мірі залежить від фази джерела напруги в момент комутації. Для аналізу найбільш важких режимів комутації було проведене математичне моделювання процесу включення світлодіодних джерел світла за формулами (8), (11) та (16) та отримані графіки залежностей i(t), представлені на рисунках (5)-(8). 
TECHNICAL SCIENCES AND TECHNOLOGIES

Система електропостачання має порівняно невеликий активний опір по відношенню до активного опору самої лампи, тому для різних варіантів протяжності електричної мережі можна вважати, що сумарний активний опір дорівнює опору лампи (близько 10 Ом). В той же час індуктивність мережі змінюється в значному діапазоні, що може призвести як до аперіодичного (рисунки 5, 6) так і до коливального (рисунки 7, 8) характеру перехідного процесу.

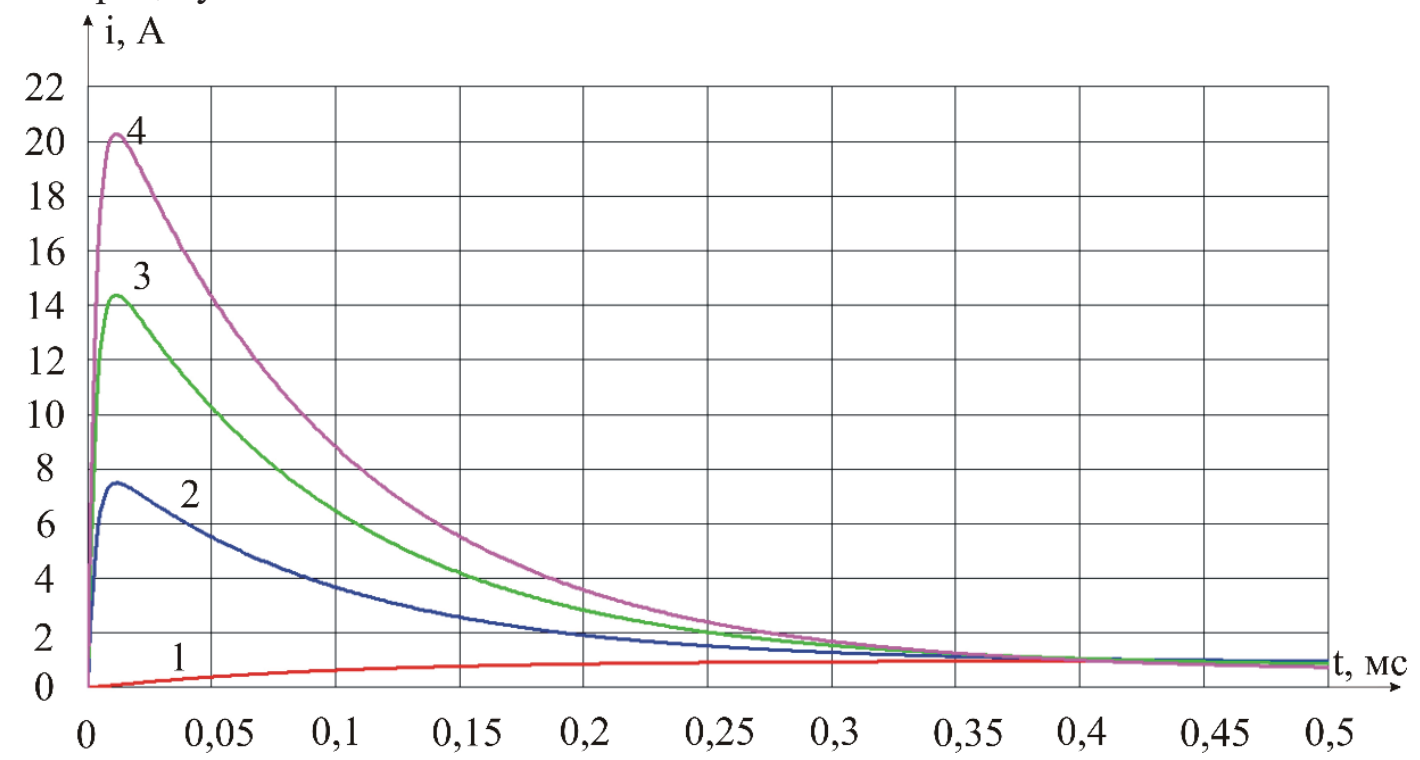

Рис. 5. Залежності зміни струму для схеми з параметрами $R=10 \mathrm{OM}, L=31,2 м \kappa \Gamma \mathrm{H}$, $C=10$ мкФ при початковій фазі напруги: $1-0^{\circ} ; 2-15^{\circ} ; 3-30^{\circ} ; 4-45^{\circ}$

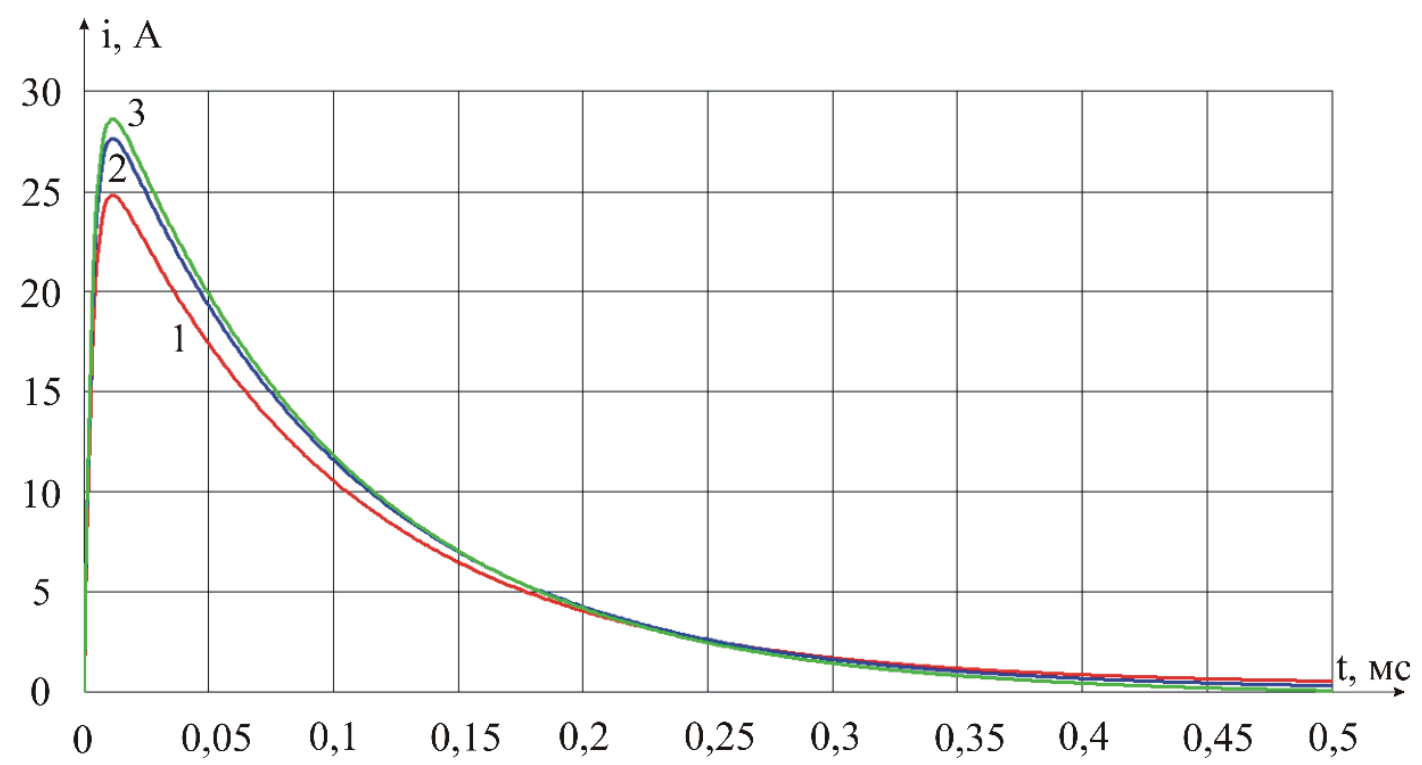

Рис. 6. Залежності зміни струму для схеми з параметрами $R=10 \mathrm{OM}, L=31,2 м \kappa \Gamma \mathrm{H}$, $C=10 м \kappa \Phi$ при початковій фазі напруги: $1-60^{\circ} ; 2-75^{\circ} ; 3-90^{\circ}$ 


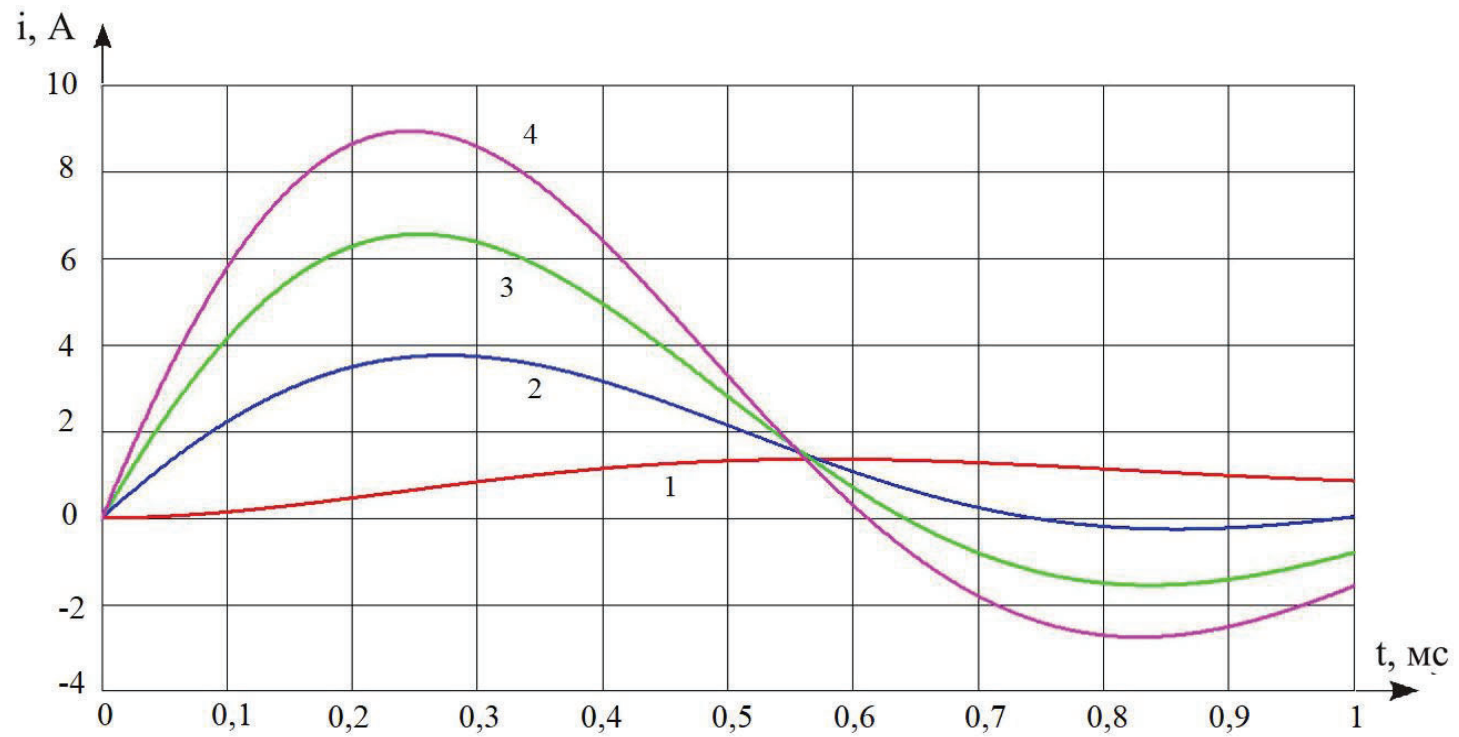

Рис. 7. Залежності зміни струму для схеми з параметрами $R=10$ Oм, $L=3,12 м \Gamma H$, $C=10 м \kappa \Phi$ при початковій фазі напруги: $1-0^{\circ} ; 2-15^{\circ} ; 3-30^{\circ} ; 4-45^{\circ}$

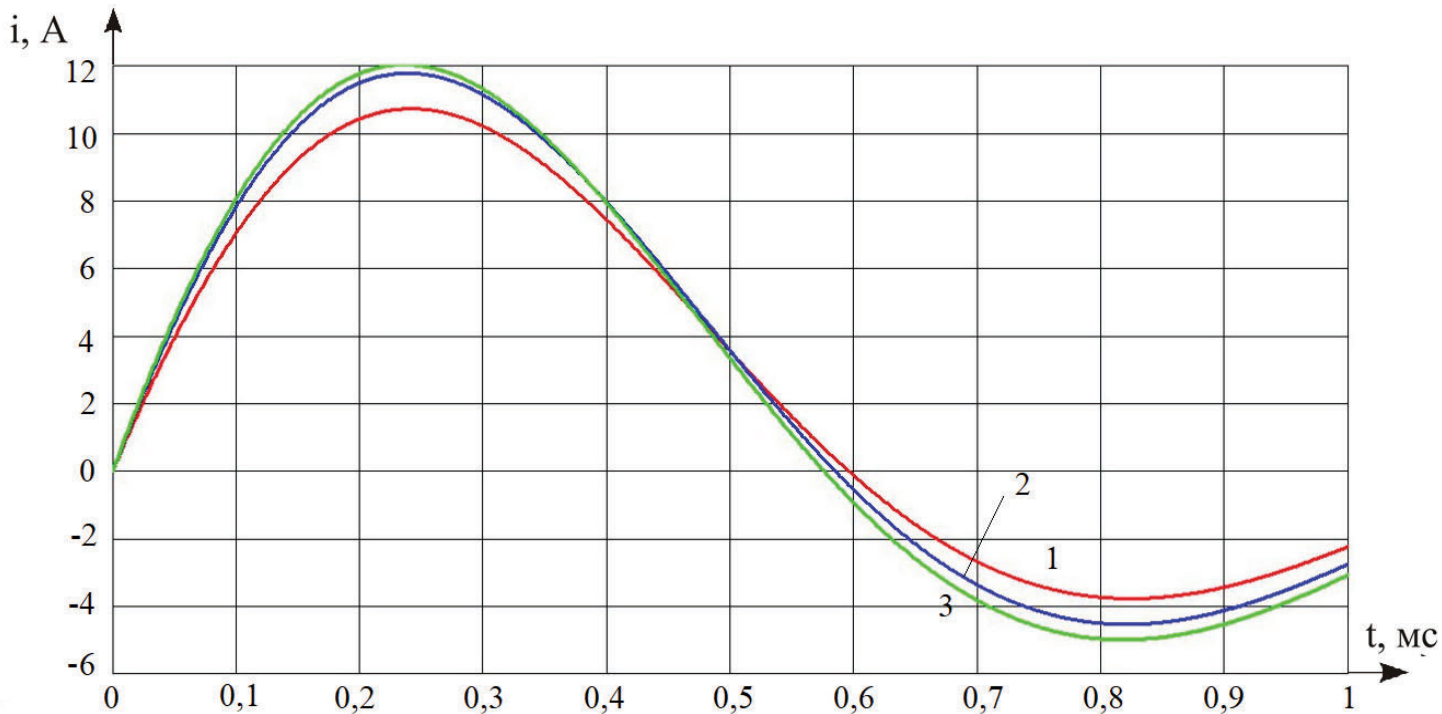

Рис. 8. Залежності зміни струму для схеми з параметрами $R=10 \mathrm{OM}, L=3,12 м \Gamma \mathrm{H}$, $C=10$ мкФ при початковій фазі напруги: $1-60^{\circ} ; 2-75^{\circ} ; 3-90^{\circ}$

Як можна побачити з наведених графіків, найбільш важкий режим може виникнути при аперіодичному характері перехідного процесу, який виникає при невеликих значеннях індуктивності мережі. Цей випадок відповідає точці приєднання споживача поблизу живлячої підстанції. За збільшення кількості паралельно включених ламп піковий струм під час включення може перевищити номінальний струм спрацювання швидкодіючих апаратів захисту і привести до їх відключення.

Висновки. У роботі отримано аналітичні залежності струму від часу при включенні світлодіодних джерел для випадків аперіодичного, гранично аперіодичного та коливального перехідних процесів.

Досліджено вплив фази напруги джерела живлення на найбільше значення пікового струму. Як видно з рисунків 5-8, найбільші пікові струми мають місце за аперіодичного характеру перехідного процесу та складають майже 30 А за номінальної потужності світлодіодних джерел світла, що не перевищує 10-20 Вт. Незважаючи на швидке затухання 
перехідного процесу (0,2-0,4 мс), такі струми можуть приводити до спрацювання апаратів захисту та перерв в електропостачанні споживачів.

В результаті моделювання визначено, що в мережах зі значною кількістю світлодіодних джерел світла піковий струм під час одночасного включення може значно перевищувати номінальний струм спрацювання швидкодіючих апаратів захисту, i, як наслідок, може призводити до їх відключення. Це необхідно враховувати при виборі параметрів апаратів захисту та кількості світлодіодних джерел, що до них приєднуються.

\section{Список використаних джерел}

1. Посібник до ДБН.В.2.5-28:2018 «Природне і штучне освітлення» Розроблено на замовлення програми UNDP в Україні / за ред. М.О. Любича, Ю.С. Громадського, І.Ю. Черкашина. К. : ДІА, 2019. - 180 с.; іл.

2. Sankaran C. Power Quality / Sankaran C. - CRC Press, 2002. - 218 p.

3. Roger C. Dugan. Electrical Power Systems Quality / Roger C. Dugan, Surya Santoso, Mark F. McGranaghan. - McGraw-Hill, 2003. - 528 p.

4. Hans De Keulenaer. Resilient power supply in a modern office building / Hans De Keulenaer, Prof Angelo Baggini // Copper Development Association: Power quality application Guide Part 5.4.1.

5. ГОСТ 13109 Нормы качества электрической энергии в системах электроснабжения общего назначения. - Введений в Україні 01.01.1999. - (Національний стандарт України).

6. ДСТУ EN 50160:2010. Характеристики напруги електроживлення, постачаної розподільчими мережами загальної призначеності. - Введений в Україні 01.07.2012. - (Національний стандарт України).

7. МЕК 61000-4-30:2008. Електромагнітна сумісність (ЕМС) - Частина 4-30: Техніка випробувань і вимірювань // Методи вимірювань показників якості електроенергії, 2008. - 59 с.

8. Скопич $Є$. І. Дослідження режиму споживання нелінійними побутовими електроприймачами при змінній напрузі живлячої електромережі / Є. І. Скопич // Новітні технології у науковій діяльності і навчальному процесі: Всеукраїнська науково-практична конференція студентів, аспірантів та молодих учених (м. Чернігів, 10-11 квітня 2019 р.) : збірник тез доповідей. - Чернігів : Черніг. нац. технол. ун-т, 2019. - С. 131-133.

9. Горський В. В. Урахування потужності спотворень при аналізі електроспоживання однофазних електроприймачів / В. В. Горський // Новітні технології у науковій діяльності і навчальному процесі: Всеукраїнська науково-практична конференція студентів, аспірантів та молодих учених (м. Чернігів, 10 -11 квітня 2019 р.) : збірник тез доповідей. - Чернігів : Черніг. нац. технол. ун-т, 2019. - С. 149-151.

\section{References}

1. Liubych, M.O., Hromadskyi, Yu.S., Cherkashyn, I.Iu. |(2019). Posibnyk do DBN.V.2.528:2018 «Pryrodne i shtuchne osvitlennia» Rozrobleno na zamovlennia prohramy UNDP v Ukraini [Manual to DBN.V.2.5-28: 2018 "Natural and artificial lighting" Developed for the UNDP program in Ukraine]. DIA.

2. Sankaran, C. (2002). Power Quality. CRC Press.

3. Roger C. Dugan, Surya Santoso, Mark, F. McGranaghan. (2003). Electrical Power Systems Quality. McGraw-Hill.

4. Hans De Keulenaer, Angelo Baggini. (n.d.). Resilient power supply in a modern office building. Copper Development Association: Power quality application Guide Part 5.4.1.

5. HOST 13109 Normy kachestva elektrycheskoi energii $\mathrm{v}$ sistemakh elektrosnabzheniia obshchego naznacheniia [Electricity quality standards in general-purpose power supply systems]. (01.01.1999).

6. DSTU EN 50160:2010 Kharakterystyky napruhy elektrozhyvlennia, postachanoi rozpodilchymy merezhamy zahalnoi pryznachenosti [Characteristics of power supply voltage supplied by general purpose distribution networks]. (01.07.2012).

7. MEK 61000-4-30:2008. Elektromahnitna sumisnist (EMS). Chastyna 4-30: Tekhnika vyprobuvan i vymiriuvan [MEK 61000-4-30: 2008. Electromagnetic compatibility (EMC) - Part 4-30: Testing and measurement techniques]. (2008). Metody vymiriuvan pokaznykiv yakosti elektroenerhii. 
8. Skopych, Ye.I. (2019). Doslidzhennia rezhymu spozhyvannia neliniinymy pobutovymy elektropryimachamy pry zminnii napruzi zhyvliachoi elektromerezhi [Research of consumption mode by nonlinear household electric receivers at alternating voltage of the power supply network]. Proceeding from Novitni tekhnolohii u naukovii diialnosti $i$ navchalnomu protsesi: Vseukrainska naukovopraktychna konferentsiia studentiv, aspirantiv ta molodykh uchenykh - Latest technologies in scientific activity and educational process: All-Ukrainian scientific-practical conference of students, graduate students and young scientists (pp. 131-133). Chernih. nats. tekhnol. un-t.

9. Horskyi, V.V. (2019). Urakhuvannia potuzhnosti spotvoren pry analizi elektrospozhyvannia odnofaznykh elektropryimachiv [Taking into account the power of distortion in the analysis of power consumption of single-phase power receivers]. Novitni tekhnolohii u naukovii diialnosti i navchalnomu protsesi: Vseukrainska naukovo-praktychna konferentsiia studentiv, aspirantiv ta molodykh uchenykhLatest technologies in scientific activity and educational process: All-Ukrainian scientific-practical conference of students, graduate students and young scientists (pp. 149-151). Chernih. nats. tekhnol. un-t.

Отримано 05.07.2021

UDC 621.311

\section{Vadim Bodunov', Ihor Dihtyaruk', Andrey Krasnozhon ${ }^{3}$}

${ }^{1} \mathrm{PhD}$ in Technical Science, Associate Professor of Electrical Engineering And Information and Measuring Technologies Department

Chernihiv Polytechnic National University (Chernihiv, Ukraine).

E-mail: vad1979@ukr.net. ORCID: https://orcid.org/0000-0003-2882-5787

${ }^{2} \mathrm{PhD}$ in Technical Science, Associate Professor of Electrical Engineering and Information And Measuring Technologies Department

Chernihiv Polytechnic National University (Chernihiv, Ukraine)

E-mail: dihtyaruk.ihor@gmail.com. ORCID: https://orcid.org/0000-0002-6565-6356

${ }^{3} \mathrm{PhD}$ in Technical Science, Associate Professor, Associate Professor of Electrical Engineering and Information and Measuring Technologies Department

Chernihiv Polytechnic National University (Chernihiv, Ukraine)

Email: red_john@ukr.net. ORCID: https://orcid.org/0000-0002-6215-7535

\section{MATHEMATICAL SIMULATION OF PEAK CURRENTS WHEN SWITCHING ON LED LIGHT SOURCES}

Urgency of the research is due to the fact that LED light sources are widely used not only in public utilities, but also in industry, in transport infrastructure. Their switching process is fast and is accompanied by the appearance of significant current and, in some cases, overvoltage on the capacitor.

Thus, target of research is necessary to identify the main features of the transient process when connected to a lowvoltage electrical network of a separate LED lamp or luminaire.

Actual scientific researches and issues analysis has shown that they are mainly devoted to the problems of higher harmonics during the operation of LED light sources, the appearance of significant current and in some cases overvoltage on the capacitor when they are turned on. It should be noted that researches of transients at inclusion are based on experiments with physical models.

Uninvestigated part of general problem is that there are no analytical research methods of transients when connected to low-voltage electric network LED light sources to select their optimal number and parameters of protection devices.

The research objective is investigation of the features of the transient process when connected of LED light sources using mathematical modeling.

The article analytically derives the current of the LED light source at the time of inclusion. Variants of periodic, aperiodic and boundary-aperiodic transients are considered. The corresponding graphs for different moments of inclusion in relation to a phase of a power supply network are resulted.

The conclusions state that the largest peak currents occur in the aperiodic nature of the transient process. The transition process attenuates in 0.2-0.4 ms. It is determined that in networks with a significant number of LED light sources, the peak current during switching on can significantly exceed the rated operating current of high-speed protection devices, and, as a consequence, lead to their switching off.

Keywords: nonlinear consumer; mathematical model; switching, peak current; led light source.

Fig.: 8. References: 9.

Бодунов В., Діхтярук І., Красножон А. Математичне моделювання пікових струмів при включенні світлодіодних джерел світла, Технічні науки та технології. 2021. № 3(25). С. 256-264. 